\title{
The Patrimonial Turn in the American State
}

\author{
Jeffrey D. Broxmeyer \\ The University of Toledo
}

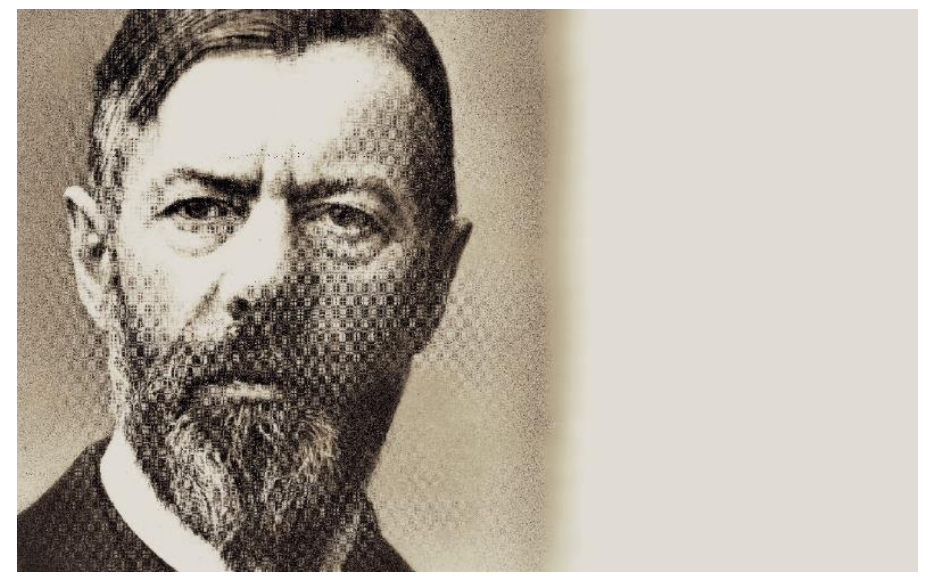

Trumpism signals a "patrimonial turn" in the American state. Consider the implications of this tendency toward rule by family and friends, and what it means for democracy. The incumbent president has superimposed the Trump Organization, a family business, and relatives who manage it, upon the political system. There has simply never been a sitting president who profited from business of this scale while in office, fusing together individual wealth accumulation with public authority. In this way, patrimonial rule is a departure from the rule bound, insulated technocratic order that has characterized the modern administrative state.

And yet, there are clear antecedents in American political development. The spoils system from days of yore, run by personalistic exploitation of public office, is an obvious point of reference. Trump's wealth accumulating practices suggest that he fully understands that offices of "honor, Trust or Profit," so referenced in the Constitution, are a species of property. Political office is not necessarily a capitalist form of property or even one that is naturally subsumed into competitive markets (Gibson-Graham 1996, xiii). However, under certain historical circumstances officeholding can-and has been-leveraged as a mode of private wealth accumulation (Broxmeyer, Forthcoming). Such practices have deep roots. There was a vibrant debate in the early Republic over emoluments that codified safeguards directly into the U.S. Constitution (Teachout 2014). Antifederalists worried that a future president might distribute appointments to generate a "numerous train of dependents," fostering relationships that smacked of aristocracy (Cato 1787). Spoils were in fact the primary motor of party organization for nearly the entire nineteenth century. The battle to strip personal use from public office was epic, lasting decades (Hoogenboom 1986; Parillo 2013). That struggle for reform has long since receded from public memory. Still, the parallel is instructive. Trump's reliance on partisan networks of personal loyalty is similar to how ambitious entrepreneurs built coalitions throughout the nineteenth century by disbursing the material perquisites of office. The public justification of his ongoing business enterprise recalls the most strident defenses of the spoils system during the Gilded Age.

\section{Patrimonialism Then and Now}

What we have, then, is a tendency that feels new and strange but is hardly unique in historical or comparative perspective. As Max Weber outlined in his classic work, patrimonialism is a form of political authority that rests upon the personal whimsy of a leader rather than established rules or legal processes. Any separation between the state and the leader collapses into a "household" model. The patriarch assumes personal ownership of the means of administration ("my generals," per Trump), and governs through kinship networks and personal loyalty (Weber 1947, 341-7; Hall 2017, 577-8). This mode of governance is typically delimited pre-modern. But there are caveats to drawing strict analytic or temporal bounds.

The "familial state" played a key role in the development of early merchant capitalism, particularly the joint-stock corporation (Adams 2005). We know that feudal lineages carried over to America (Orren 1991). The nineteenth-century American state, for instance, distributed monopoly resources in patrimonial fashion like access to land and other grants or privileges (Hall 2015). Mass democracy was made possible, in part, by channeling mobilization through clientelistic networks of office-hungry partisans. Gilded Age reformers complained that party spoils produced a host of evils: waste, nepotism, pelf, and the appointment of "dishonest henchmen or incompetent supernumeraries" (Eaton 1881, 14). (continued on p. 20) 
Broxmeyer (continued from p. 6) More recently, scholars have demonstrated that elements of patrimonialism exist in a wide range of historical and comparative contexts, including modern societies (Adams and Charrad 2015). Patriarchy in gender relations remains hegemonic at the peak of social and political institutions. Last year, $95 \%$ of all Fortune 500 CEOs were men (Zarya 2018); all presidents have been up to present. During the 2016 elections, Trump demonstrated the political viability of a program to reconstitute social hierarchies anew in the face of evolving gender norms and family structure. Within the economy, family businesses like the Trump Organization play an important role, even in the age of corporate consolidation. It is no coincidence that dynastic inheritance itself is a defining feature of the exploding wealth gap (Picketty 2015, 24, 290-303, 411, 414). Generational wealth transfer has proven a central project of The Long Reagan Coalition, which places a first-order emphasis on elimination of the Estate Tax (Martin 2013, 182-194). Trump's evasion of personal and corporate taxes over the decades aligns him as a beneficiary of tax policy to unburden wealthy families (Barstow, Craig, Buettner 2018).

Herein lies the rub. Patrimonialism is about congealing capital into state privileges as part of an intensifying circuit of accumulation. One major question is whether Trump is leading the charge or following. There is a general trend domestically in finance, health, and energy sectors toward codifying state privileges-one way to interpret the veritable revolution in corporate lobbying since the 1980s. We must also see the contemporary patrimonial turn from a comparative lens. We live in a new golden age of state-led capitalism (Kurlantzick 2016). Goals of the nation-state and its leading firms are increasingly blurred. The Chinese model, managed by the so-called "princelings," or the children of senior officials, is one of the more successful variants. Given China's rising global profile, we should be wary of dismissing the possibility that the cutting-edge of political economy might once again be patrimonial.

\section{Why Patrimonialism?}

Patrimonial rule is how Trump looks to solve problems of collective action. For one, Trump's partisanship has little to do with meaningful group affiliation or ideology in the conventional sense, even as he benefits from a polarized landscape. But it is also true that today's Republican Party itself is having difficulty coordinating by conventional means (Noel 2018). There appears to be little internal consensus outside of tax policy, and thus, there was little policy innovation during unified party control of government from 2017-2019. Much of the Republican Party's traditional office holding caste declined to serve in the administration or took themselves out of party markets by signing public letters condemning Trump. Under these circumstances, ad hoc coordination by personal rule binds together, if tenuously, party regulars and vested partners (singleissue groups, the business lobby, or mega-donors), with far right movement figures. 
Most conspicuous is the patrimonial turn in staffing the executive branch. Trump appointees appear to have little formal expertise relevant to their posts. Technocrats like H.R. McMaster, the former National Security Advisor, or Gary Cohn, the former Goldman Sachs CEO turned economic advisor, do not last very long or retain much influence. By contrast, the president's personal entourage is empowered precisely because of proximity to Trump and his level of comfort with them. One example is the appointment of Keith Schiller, Trump's longstanding personal bodyguard, to senior positions in the White House. Another example is the nomination of the president's doctor, Ronny Jackson, to head the Department of Veterans Affairs, among the largest and most complex bureaucracies in the federal government, with a budget of $\$ 200$ billion and over 377,000 employees. The Senate declined to confirm precisely due to the chasm between the department's political salience and Jackson's lack of credentials. The pattern is also emblematic of Ben Carson's placement at Housing and Urban Development, with whom Trump enjoys a warm personal rapport, and Secretary of Commerce Wilbur Ross, a longtime business associate. Patrimonial-style appointments with "acting" instead of permanent powers are becoming the norm. Meanwhile, party functionaries and ideologues are increasingly rare, or have embraced the patrimonial style to adapt.

Traditional chiefs of Staff like Reince Priebus and John Kelly failed because they enjoyed none of tools necessary to manage White House operations. Neither had the ability to hire and fire staff, nor gatekeeping control over access to the president or his schedule (Cohen 2018). Under Trump, no single figure is allowed to coordinate the administration's political agenda with the policy process. Trump's family-Ivanka and her husband, Jared Kushner-fill the subsequent power vacuum. The "Javanka" duo enjoy the quintessential patrimonial portfolio: everything is their prerogative, while they are experts in nothing. The leader has brushed away legal obstacles like anti-nepotism rules and security clearances. Lack of expertise and Javanka's ever-shifting gaze means there is little sustained attention to major foreign or domestic issues with which they engage, from Mideast diplomacy to government shutdowns.

\section{Deconstructing the Administrative State}

The patrimonial turn is an unexpected consequence of The Long Reagan Coalition's program to de-construct the modern administrative state. Described on its own terms, the principal aim is to unleash free enterprise by deregulating the economy. The goal requires diminishing or abolishing federal agencies that write and enforce rules constraining the investment behavior of firms and wealthy individuals. When political scientists speak of the state's "relative autonomy" from any one social class or group, we identify political institutions as a force in their own right (Skocpol 1985). For example, the contemporary bureaucratic rulemaking process insulates policy from some direct outside pressures. Even the most propertied organized interests must sustain a high level of collective action to influence desired outcomes, especially if they seek to overturn or replace current rules. Any political program to remove the federal administrative burden would, in theory, allow for the objectives of political actors to be achieved quicker, far more directly, and without public consultation.

President Trump has taken steps in this direction. The administration's first proposed budget, overseen by OMB Director Mick Mulvaney, a founding member of the House Freedom Caucus, outlined a visionary blueprint to defund federal agencies outside of the national security apparatus. "America First: A Budget To Make America Great Again" called for sweeping spending reductions across 18 agencies, with cuts to the Departments of Agriculture, Labor, and State that would have effectively shuttered most functions. Congress has not embraced the president's plan for retrenchment. Nevertheless, administrative capacity has undergone significant decomposition. For one, the president's political team has weaponized workforce attrition. At the State Department, $60 \%$ of top-ranking career diplomats left within the first two years of the Trump Administration. An exodus of thousands of Environmental Protection Agency officials has also left without any plans for their replacement, shrinking the department by $8 \%$ in the first year (Stephenson 2018; Dennis, Eilperin, Ba 2018). Year Two's 35-day government shutdown-the longest in American history - had the effect of shock therapy. More hammer than scalpel, federal agencies were brought to a screeching halt, causing personnel dislocations and farreaching damage to governing capacity.

Superficial connection to the traditional agency decisionmaking and information-sharing process gives Trump's Twitter pronouncements a quality akin to those of ancien régime sovereigns. Kings, tsars, and viziers frequently announced initiatives to great fanfare. New policy directions were often celebrated but ignored, and the world quickly moved on to the next fashionable item or crisis (Skocpol 1979, 47-99). Along with Trump's emphasis on marketing, top agency officials pay so little attention to the Administrative Procedure Act, the main obstacle to arbitrary rule in the executive branch, that federal judges have overturned an unprecedented number of decisions for basic process violations 
(Barbash and Paul 2019). Then again, who will enact new rules, however they are decided? Three years into this administration, nearly one-quarter of top positions requiring Senate confirmation are vacant. High turnover continues to be an ongoing obstacle (Partnership For Public Service 2019). Without administrative capacity to make decrees happen, policy is poorly implemented or even blocked entirely by competing interests.

\section{Rebuilding the Familial State}

Has the Trump family business supplanted federal agencies as the focal point of executive lobbying? The process of administrative "deconstruction" is occurring as the Trump Organization moves to the center of public life. Since the inauguration, Trump properties have become prime venues for spending by interest groups, businesses, and foreign governments looking for presidential favor. Most clearly, the Trump International Hotel is a new locus of party spoils. Located just down the street from the White House, the hotel runs on a government lease (GSA 2019). Its grand opening was timed as the president took office. The D.C. hotel alone reported $\$ 40$ million in profits for 2018 , or about $10 \%$ of the Trump Organization's total revenue (Eder, Lipton, and Armendiaz 2019). Other emoluments garner attention for their potential foreign policy implications. The Saudi government single-handedly rescued the profitability of the president's New York hotel in 2018. More recently, the communications giant T-Mobile spent \$200,000 at Trump International while seeking regulatory approvals (Maritz and Elliot 2018; Fahrenthold and O'Connell 2018). No fewer than 53 members of Congress have patronized the full spectrum of Trump properties, raising novel questions about the separation of powers.

Becoming a client of the Trump Organization is a unique way to patronize the president directly, as a public demonstration of loyalty. The top four spenders in the Trump International Hotel's first year were the Republican National Committee, the president's own election campaign, the Republican Governor's Association, and a pro-Trump SuperPAC. Party spending is part of a circuit of capital that flows among donors and various political vehicles, from law firms and political nonprofits to party committees (CREW 2018). If reporting is accurate, Trump even describes political contributions as his own money (Woodward 2018, 42; Lewis 2018, 20-2). He also considers public money at personal disposal. Executive branch officials spend freely at Trump properties. The State Department now employs a credit card whose exclusive purpose is covering expenses at Mar-a-Lago (Kravitz and Willis 2018; Kravitz 2019).
The collapsing distinction between public and private money is a quintessential feature of patrimonialism. Central to governance under Trumpism is how the president prefers to build alliances via the mutual accumulation of wealth. For one, property binds people together who might not otherwise have much in common, politically, culturally, or ideologically. Donald Trump's ever-changing cast of political advisors, for instance, has cycled out of official positions and set up their own companies to monetize access to the president ("Essential Services LLC"), with the intention of servicing clients with deep pockets. Selling influence is a risky venture for political entrepreneurs, not only for the unwanted public scrutiny, but also for potential legal pitfalls. High profile former Trump advisors, including Michael Cohen, Paul Manafort, Richard Gates, Roger Stone, George Papadopoulos, and Michael Flynn, solicited millions in fees from corporate clients and foreign governments. Several of them ended up cooperating with investigations by Special Prosecutor Robert Mueller that placed the Trump presidency in political jeopardy. Transactional alliances based on property tend to be shallow, temporary, and prone to a constant renegotiation of terms.

\section{Paths Before Us}

Will patrimonialism take hold in America over the long term? After all, the presidency is the institution that carries our politics onto new ground, periodically reconstructing the American state (Skowronek 1997). It is premature to assess whether rule by family and friends is here to stay. Still, the "search for American political development" is about roads taken and those abandoned (Ritter 1999, 9-25; Orren and Skowronek 2004). One possibility is that an overwhelming public reaction empowers Congress or the courts to foreclose patrimonialism, much as presidential discretion was limited after prior abuses. If any such public consensus were forged, the subsequent reaction to presidential power would likely be filtered through the lens of our current party polarization. Today, political obstacles in public opinion and party are layered on top of the already substantial inertia built into the Madisonian system of separated powers.

Another route that lies before us is the spread of patrimonialism via the presidency's demonstration effect. Looking at the Trump model, ambitious political entrepreneurs might unleash a host of experiments at the national, state, or local level. The fusion of personal business and government could well become a standard feature of the party system, or perhaps by crystalizing only within the Republican Party, yet another artifact of asymmetric polarization (Grossmann and Hopkins 
2016). Still another distinct path is a middle ground: the incoherence of maladministration. Max Weber was the first to argue that the arbitrariness of patrimonial rule lies in tension with legal-rational administration. Conceivably, the partial implantation of patrimonial modes could persist within the interstices of the American state, never fully prohibited or legitimized. Scholars of comparative politics would recognize such an institutional matrix, where the rule of law is weak but the consolidation of power into the hands of a political elite provides elements of stability and continuity.

At minimum, the debate over Trump's impact on the political system is a call to reevaluate longstanding presumptions. Before 2016, the idea that the technocratic strata of the state might be undone, say by a patrimonial revival, would have been considered fanciful by most scholars of American politics. The Obama Administration's embrace of technocratic solutions certainly places the patrimonial turn in sharp relief. And thus, the Trump moment upends a whiggish view of public administration that prevails not only among journalists and commentators but also political scientists. The modern administrative state is not the permanent future, after all. If it were to be successfully deconstructed, we might do well to ask ourselves what exactly follows in its place.

\section{References}

Adams, Julia. The Familial State: Ruling Families and Merchant Capitalism in Early Modern Europe. Cornell University Press, 2005.

Adams, Julia and Mounira Charrad. "(Old) Patrimonial Forms Made New," Political Power and Social Theory 28 (2015): 1-5.

Barbash, Fred and Deanna Paul. "The Real Reason the Trump Administration Is Losing in Court," Washington Post, March 19, 2019.

Barstow, David, Suzanne Craig, and Russ Buettner. "Trump Engaged in Suspect Tax Schemes as He Reaped Riches from His Father," New York Times, October 18, 2018.

Broxmeyer, Jeffrey. Electoral Capitalism: The Party System in New York's Gilded Age. University of Pennsylvania Press, Forthcoming.

Cato. "Various Fears Concerning The Executive Department," Antifederalist Number 67 (1787).

Citizens for Responsibility and Ethics in Washington. Profiting from the Presidency, January 19, 2018, https://www.citizensforethics.org/profitingfromthepresidency/.

Cohen, David. "John Kelly Was Always Doomed To Fail," The Hill, December 8, 2018.

Dennis, Brady, Juliet Eilperin, and Andrew Ba Tran. "With Shrinking EPA, Trump Delivers On Promise To Cut Government," Washington Post, September 8, 2018.

Eaton, Dorman. The Spoils System and Civil Service Reform. G.P. Putnam's Sons, 1881.

Eder, Steve, Eric Lipton, and Agustin Armendiaz, "Trump's Financial Disclosure Shows Mixed Results For His Business In 2018," New York Times, May 16, 2019.

Fahrenthold, David and Jonathan O'Connell, "Saudi-Funded Lobbyist Paid for 500 Rooms At Trump's Hotel After 2016 Election," Washington Post, December 5, 2018.

Gibson-Graham, J-K. The End of Capitalism (As We Knew It): A Feminist Critique of Political Economy. University of Minnesota Press, 1996.

General Services Administration. "Evaluation of GSA's Management and Administration of the Old Post Office Building Lease," January 16, 2019.

Grossmann, Matthew and David Hopkins. Asymmetric Politics: Ideological Republicans and Group Interest Democrats. Oxford University Press, 2016.

Hall, John. "Patrimonialism," Handbook of Political Behavior. Sage Press, 2017.
. "Patrimonialism in America: The Public Domain in the Making of Modernity, From Colonial Times To The Late Nineteenth Century." Political Power and Social Theory 28 (2015): 7-41.

Hoogenboom, Ari. Outlawing the Spoils: A History of the Civil Service Reform Movement, 1865-1883. University of Illinois Press, 1986.

Kurlantzick, Joshua. State Capitalism: How The Return of Statism Is Transforming The World (Oxford University Press, 2016).

Kravitz, Derek. "How Taxpayers Covered a \$1,000 Liquor Bill for Trump Staffers (and More) at Trump's Club," ProPublica, May 1, 2019.

Kravitz, Derek and Derek Willis. "Paying the President," ProPublica, June 27, 2018, https://bit.ly/2T1Ywc2.

Lewis, Michael. The Fifth Risk. W.W. Norton, 2018.

Maritz, Ilya and Justin Elliot. "Trump Inauguration Paid Trump's Company-With Ivanka in The Middle," ProPublica, December 18, 2018.

Martin, Isaac. Rich People's Movements: Grassroots Campaigns to Untax the One Percent. Oxford University Press, 2013).

Noel, Hans. "The Activists Decide: The Preferences of Party Activists In The 2016 Presidential Nominations." Journal of Elections, Public Opinion, and Parties 28:2 (2018): 225-244.

Orren, Karen. Belated Feudalism: Labor, Law, and Liberal Development in the United States. Cambridge University Press, 1991.

Orren, Karren and Stephen Skowronek. The Search for American Political Development. Cambridge University Press, 2004.

Parillo, Nicholas. Against the Profit Motive: The Salary Revolution in American Government, 1780-1940. Yale University Press, 2013.

Partnership for Public Service. "Tracking How Many Positions Trump Has Filled So Far,” Washington Post, updated May 20, 2019, https://wapo.st/2JIA7nz.

Picketty, Thomas. Capital in the Twenty-First Century, A. Goldhammer, trans. Belknap Press, 2015.

Ritter, Gretchen. Goldbugs and Greenbacks: The Antimonopoly Tradition and the Politics of Finance in America, 1865-1896. Cambridge University Press, 1999.

Skocpol, Theda. States and Social Revolutions. Cambridge University Press, 1979.

. "Bringing the State Back In: Strategies of Analysis in Current Research," Bringing the State Back In, P. Evans, D. Rueschemeyer, T. Skocpol, eds. Cambridge University Press, 1985. 
Skowronek, Stephen. The Politics Presidents Make: Leadership from John Adams to Bill Clinton. Belknap Press, 1997.

Stephenson, Barbara. “Time To Ask Why," American Foreign Service Association, December 2017.

Teachout, Zephyr. Corruption in America: From Benjamin Franklin's Snuff Box to Citizens United. Harvard University Press, 2014.
Weber, Max. Theory of Social and Economic Organization, A.M. Henderson and T. Parsons, trans. Oxford University Press, 1947.

Woodward, Bob. Fear: Trump in the White House. Simon and Schuster, 2018.

Zarya, Valentina. "The Share of Female CEOs in the Fortune 500 Dropped By 25\% in 2018," Fortune, May 21, 2018. 